ELEMEN ESTETIS KOREOGRAFI TARI CANG-CANG DI KAYUAGUNG KABUPATEN OGAN KOMERING ILIR

Emy Admala Yuliarti

KONSEP KEBERSAMAAN DALAM TRADISI MIDANG MABANG HANDAK PADA MASYRAKAT MORGESIWE KECAMATAN KAYUAGUNG

A. Heryanto

PANGLIMA LAOQT SEBAGAI LOCAL WISDOM MASYARAKAT NELAYAN PESISIR ACEH (STUDI KASUS TENTANG PANGLIMA LAOQT LHOK KECAMATAN SERUWAY KABUPATEN ACEH TAMIANG)

Purnama Sari \& Puspitawati

PENERAPAN MODEL PEMBELAJARAN COURSE REVIEW HORAY TERHADAP KEMAMPUAN MENJELASKAN ALUR CERPEN UNTUK ANAK SDN 52 PALEMBANG Sri Wahyu indrawati

PENGARUH MODEL PEMBELAJARAN ARTIKULASI TERHADAP KEMAMPUAN MENULIS PADA SMP NEGERI 2 PALEMBANG

Yus Vernandes Uzer

PENGARUH MODEL PEMBELAJARAN COMPLETE SENTENCE TERHADAP KEMAMPUAN MENULIS PADA SMP NEGERI 13 PALEMBANG

Yuspar Uzer

$60-70$

PENGARUH MUSIK ANSAMBEL TERHADAP KECERDASAN EMOSI REMAJA

Novdaly Fillamenta \& Mohammad Arfani

PEWAISAN RABAB PIAMAN DI KECAMATAN LUBUK ALUNG

KABUPTEN PADANG PARIAMAN

Irfan Kurniawan

$82-93$

ESTETIKA MOTIF NAGO BESAUNG PADA KAIN SONGKET PALEMBANG Decky Kunian

BENTUK GERAK TARI KAIN DI SANGGAR DEWAN KESENIAN MUSI RAWAS

Pransiska Sepriyanti 


\title{
ELEMEN ESTETIS KOREOGRAFI TARI CANG-CANG DI KAYUAGUNG KABUPATEN OGAN KOMERING ILIR
}

\author{
Oleh: \\ Emy Admala Yuliarti \\ (Guru Seni Budaya Kota Kayuagung)
}

\begin{abstract}
Abstrak
Tari Cang-Cang merupakan tarian khusus dalam upacara adat perkawinan yang diperuntukan bagi kedua belah mempelai yang ada di Kayuagung. Elemen estetis koreografi tari Cang-Cang adalah dasar dari dalam tari yang tidak dapat terlepas dari kesatuan yang merupakan gerak-ruang-waktu. Permasalahan dalam penelitian ini adalah "bagaimanakah Elemen Estetis Koreografi tari CangCang". Tujuan dari penelitian ini adalah untuk mendeskripsikan bagaimanakah elemen estetis koreografi tari Cang-Cang di Kayuagung Kabupaten Ogan Komering llir dengan menggunakan teori Y.Sumandio Hadi yang meliputi gerak sebagai elemen estetis koreografi, ruang sebagai elemen estetis koreografi, waktu sebagai elemen estetis koreografi. Metode penelitian yang digunakan oleh peneliti adalah metode kualitatif yang terdiri dari teknik observasi, wawancara dan dokumentasi dalam mengumpulkan data mengenai elemen estetis koreografi tari Cang-Cang di Kayuagung. Dari hasil penelitian yang didapat, peneliti menyimpulkan bahwa tari Cang-Cang adalah sebagai tari tradisional modern yang memiliki makna yaitu memberikan sajian khusus kepada tamu yang datang dan sebagai simbolis adanya ikatan bebesanan. Hasil penelitian berdasarkan konsep Y.Sumandio Hadi bahwa kesatuan tari yang utuh tidak dapat dipisahkan terdiri dari gerak-ruang-waktu.
\end{abstract}

Kata Kunci : Elemen estetis, koreografi, tari Cang-Cang.

\section{A. PENDAHULUAN}

Seni merupakan keindahan, ia merupakan ekspresi ruh dan budaya manusia yang mengandung dan menggungkapkan keindahan. Seni lahir dari sisi terdalam manusia didorong oleh kecendrungan seniman kepada yang indah, apapun jenis keindahan itu (Supriantini, 2014:11).

Seni sebagai kebutuhan hasrat hidup menjadikan manusia selalu mencari dan mencari segala sesuatu yang berkaitan dengan seni baik itu bentuk sampai pada definisi-definisi tetang seni. Seni berasal dari bahasa Sansekerta, yang artinya kurang lebih sebagai penyembahan, pelayanan, dan pemberian(Bahari, 2014:61).

Seni tari merupakan seni yang dapat diserap melalui indra penglihatan, dimana keindahannya dapat dinikmati dari gerakan-gerakan tubuh, terutama gerakan kaki dan tangan, dengan ritmeritme teratur, yang diiringi irama musik 
yang diserap melalui indra pendengaran (Bahari, 2014:56).

Pada dasarnya seni tari merupakan perpaduan dari beberapa unsur yang paling besar atau elementer dari cabang-cabang seni, diantaranya: gerak tubuh sebagai media garap tari, bunyi dan bahasa sebagai media garap iringan, serta seni rupa yang diaktualisasikan lewat media garap rias dan busana yang semuanya dipadukan menjadi satu. Berdasarkan teori-teori yang ada dapat disimpulkan bahwa seni tari adalah ungkapan jiwa melalui gerak tubuh dengan menggunakan keterampilan kaki dan tangan serta diiringi irama musik dapat dinikmati oleh indra penglihatan dan indra pendengaran.

Kabupaten Ogan Komering llir (OKI) memiliki beragam kebudayaan yang dimiliki setiap daerah salah satunya yaitu kebudayaan kesenian tari pada upacara adat perkawinan Mabang Handak, yang berarti Burung Putih, adat perkawinan ini disebut dengan sebutan Begawai/Begorok yaitu suatu pesta besar dalam upacara adat perkawinan. Dalam persedekahan Mabang Handak ini semua aturan maupun properti sebagai persyaratan persedekahan dimulai dari peminangan sampai terjadinya proses persedekahan. Inilah yang menjadi keunikan adat perkawinan Kayuagung yang penuh dengan nuansa adat istiadat.

Keunikan dan ciri khas tersendiri yang dimiliki oleh Kayuagung Kabupaten Ogan Komering llir yakitu beberapa potensi kesenian karena tarian yang diciptakan memiliki sejarah turun temurun dari nenek moyang terdahulu seperti: tari Lilin Bepinggan, tari Penguton, tari Gopung, tari Belanger, tari Telunjuk Sakti, tari Nope, tari Bujang Bagan dan sejenisnya tari yang berfungsi untuk pergaulan dan tontonan (Saudi, 2003:18). Salah satunya tari Cang-Cang, tari Cang-Cang yang merupakan tarian kota Kayuagung yang sudah ada, diciptakan oleh Nyonya Eli Tokia pada tahun 1962 dan dikembangkan kembali pada tahun 1978 oleh Bapak Yuslizal. Pada tahun 2001 tari Cang-Cang ditampilkan di Taman Mini Indonesia pada acara pergelaran seni.

Berdasarkan pola garapan tari Cang-Cang termasuk tari tradisi yang merupakan bagian dari adat istiadat propesi persedekahan, tari ini 
berkembang dimasyarakat. Tari CangCang artinya mengangkat kain setinggi tungkai atas dalam bahasa Kayuagung yaitu Nyancangkan Sarong. Tari Cang-Cang adalah sejenis tarian pergaulan yang bertujuan untuk mengajak tamu undangan tertentu agar ikut menari bersama diatas panggung dengan para penari yang mengenakan gaun kebaya kurung sebagai kebaya adat, dan dilengkapi dengan properti selendang yang akan digunakan para penari untuk dikalungkan pada leher tamu undangan bebesanan dan kemudian diajak menarikan gerakan yang bersifat spontan dari masing-masing penari. Pada awal tarian ini para penari menggunakan gerakan yang tertata, akan tetapi, setelah penari menarik penonton, maka gerakan disesuaikan dengan kemampuan orang yang ditarik untuk ikut menari.

Seiring dengan perkembangan zaman dari masa ke masa ikut berpengaruh pada perkembangan tari Cang-Cang yang ada di Kayuagung Kabupaten Ogan Komering llir. Hal ini dikarenakan oleh kebutuhan masyarakat akan kemajuan ilmu dan teknologi yang tidak dapat dibendung yang semakin membesar komunikasi antar daerah. Pemerintah daerah setempat telah menujuk Dinas Kebudayaan yang telah bergabung dalam intansi Dinas Pariwisata, dibidang pembinana kebudayaan yang telah mengangkat, mengelolah dan mengikutsertakan kembali tari CangCang dengan berbagai kegiatan kesenian daerah.

Dalam kajian ini, peneliti melihat bahwa elemen estetis yang ada pada tari Cang-Cang belum diteliti atau diuraikan kedalam tulisan atau uraiaan, dengan banyaknya perkembangan gerak tari Cang-Cang yang dianggap unik oleh peneliti dan menarik untuk diteliti. Maka dari itu, berdasarkan uraian diatas penulis tertarik mengadakan penelitian terhadap tari Cang-Cang di Kayuagung Kabupaten Oki. Dalam penulisan ini penulis mengangkat judul "Elemen Estetis Koreografi Tari Cang-Cang di Kayuagung Kabupaten Ogan Komering llir".

\section{B. METODE PENELITIAN}

Metode penelitian Kualitatif adalah metode penelitian yang berlandaskan pada filsafat 
postpositivisme, digunakan untuk meneliti pada kondisi objek yang alamiah, dimana peneliti sebagai instrumen kunci, teknik pengumpulan data dilakukan secara triangulasi (gabungan), analisis data bersifat induktif/kualitatif, dan hasil penelitian kualitatif lebih menekankan makna dari pada generalisasi. Metode ini disebut juga sebagai metode artistik, karena proses penelitian lebih bersifat seni, dan disebut sebagai metode interpretive karena data hasil penelitian lebih berkenaan dengan interprestasi terhadap data yang ditemukan dilapangan (Sugiono, 2011:3).

Penelitian pada elemen estetis koreografi tari Cang-Cang menggunakan jenis metode deskriptif kualitatif. Pendekatan kualitatif dengan cara membuat gambaran secara akurat dan sistematis mengenai elemen estetis koreografi tari CangCang di Kayuagung Kecamatan Ogan Komering llir.

\section{HASIL PENELITIAN DAN}

\section{PEMBAHASAN}

Tari Cang-Cang termasuk tari tradisi yang merupakan bagian dari adat istiadat propesi persedekahan, tari ini berkembang dimasyarakat. Tari Cang-Cang artinya mengangkat kain setinggi tungkai atas dalam bahasa Kayuagung yaitu Nyancangkan Sarong. Tari Cang-Cang adalah sejenis tarian pergaulan yang bertujuan untuk mengajak tamu undangan tertentu agar ikut menari bersama diatas panggung dengan para penari yang mengenakan gaun kebaya kurung sebagai kebaya adat, dan dilengkapi dengan properti selendang yang akan digunakan para penari untuk dikalungkan pada leher tamu undangan bebesanan dan kemudian diajak menarikan gerakan yang bersifat spontan dari masingmasing penari. Pada awal tarian ini para penari menggunakan gerakan yang tertata, akan tetapi, setelah penari menarik penonton, maka gerakan disesuaikan dengan kemampuan orang yang ditarik untuk ikut menari.

Arti dari Cang-Cang ialah mengangkat kain setinggi tungkai atas sampai Tercang-Cang pada hakikatnya tari Cang-Cang merupakan tarian tradisional namun seiring berjalanya waktu terjadi penambahan gerak. Berbeda dengan jenis tari lainnya, tari Cang-Cang ditampilkan pada saat penghujung acara pesta perkawinan 
sebagai hiburan kegembiraan atau hiburan masyarakat yang sekaligus melibatkan penonton ikut menari.

Pada dasarnya tari Cang-Cang terdiri dari 2 versi yakitu versi tradisional dan modern. Pada tahun 1962 seorang koreografer pencipta asli tari Cang-Cang Nyonya Eli Tokia beliau tertarik adanya tari Cang-Cang kuno yang ditarikan oleh Bapak-bapak Ibu-ibu saat bagian dari pada prosesi pernikahan yang ada didaerah Kayuagung. Nyonya Eli Tokia menciptakan tari Cang-Cang modern ini dikarenakan beliau tertarik dengan gerakan-gerakan kaku yang perlu dikembangakan dan memiliki makna bagi anak-anak remaja jadi pada hakikatnya tari Cang-Cang modern ini diciptakan khusus untuk para remaja.

\section{Elemen Estetis Koreografi Tari Cang-Cang}

Elemen estetis koreografi merupakan isi atau dasar dari dalam tari yang tidak dapat terlepas dari kesatuan yang merupakan gerakruang-waktu sebagai dasar dari seorang koreografer untuk menjadikan suatu rancangan dalam suatu susunan sebuah karya tari.

a. Elemen estetis gerak
Gerak merupakan bagian dari dalam kehidupan dan juga gerak merupakan dasar dari sebuah ekspresi pengalaman emosional diekspresikan lewat perasaan, imajinasi gerak tubuh. kemudian gerakan-gerakan tersebut diolah menjadi bentuk yang dapat dikomunikasikan lewat perasaan.

\section{a.1. Gerak Movement}

Gerak Movement sendiri merupakan sebuah rancangan gerak yang diciptakan langsung oleh koreografer atau gerak yang sudah disusun dalam perencanaan seperti gerakan suatu perpindahan gerak tari dari tempat gerak satu ketempat lainnya.

\section{Gerak lapah ngapai}

Gerak lapah ngapai adalah jalan menggapai atau ancang-ancang gerak awal yang tujuannya persiapannya bahwa tariaan ini akan melibatkan penonton. gerak lapa ngapai terdapat perpindahan tempat dari gerak awal dibelakang sudut panggung lalu berpindah kesudut depan panggung.

\section{Gerak ngehasta pogat}

Garak ngehasta pogat merupakan menghasta setengah tidak selebar keparan tangan. gerak ngehasta pogat terdapat perpindahan tempat dari 
gerak awal menghadap kesamping kanan berubah menjadi menghadap kearah samping kiri.

3. Gerak belibis

Gerak belibis merupakan gerakan ini diumpamakan seperti sikap tingkah laku burung belibis. Gerak belibis terdapat perpindahan tempat dari gerak awal mengarah ke sudut depan panggung lalu berpindah kesudut belakang panggung.

\section{Gerak ngotikkon jeriji}

$$
\text { Gerak ngotikkon jeriji }
$$

merupakan mengelintirkan jari jemari.

Gerak ngotikkon jeriji terdapat perpindahan tempat dari gerak awal menghadap kesamping kanan berubah menjadi menghadap kearah samping kiri.

5. Gerak beguyong kiri kanan

Gerak beguyong kiri kanan merupakan menggoyangkan tubuh kekiri dan kekanan. terdapat perpindahan tempat dari gerak awal menghadap kesamping kanan berubah menjadi menghadap kearah samping kiri.

\section{a.2. Gerak Motion}

Gerak Motion merupakan kebalikan dari gerak Movement dimana gerak Motion terjadi secara sepontan atau gerakan yang tidak direncanakan atau tersusun sebelumnya oleh seorang koreografer. Didalam tari Cang-Cang sendiri yang dikatakan gerak Motion sendiri adalah gerak pada saat penari mengajak tamu untuk ikut menari diatas panggung dengan menyesuaikan kemampuan gerak tamu yang diajak tersebut.

1. Gerak nyung sung tamu Gerak nyung sung tamu merupakan menjemput tamu. Bahwa penari baik perempuan maupun laki-laki turun dari pentas untuk menjemput tamu dengan mengalungkan selendang keleher tamu, tujuan diajak kepentas melakukan gerakan rancak dalam formasi lingkaran, dan jerambah.

2. Gerak begilir nongah

Gerak begilir nongah merupakan penari dan tamu secara bergilir menari kedalam lingkaran. Maksudnya menciptakan kebersamaan tanpa latar belakang.

3. Gerak jerambah

Gerak jerambah maksudnya membuat pormasi bersap dan berhadapan setiap pasangan dengan menguntai selendang. Gerak jerambah ini mengisyaratkan bahwa sebagai penyambung untuk menjalin silaturahmi. 
4. Gerak nyeruksuk

Gerak nyeruksuk merupakan merunduk. Setiap pasangan secara bergantian merunduk melewati jembatan yang lain. Setelah gerak nyeruksuk selesai semua penari langsung hormat mengambil selendang dan mengantarkan tamu kembali ketempat duduk semula.

\section{Elemen Estetis Ruang}

Ruang adalah sesuatu yang tidak bergerak atau bisu sampai gerak yang terjadi didalamnya mengintrodusir waktu, dan dengan cara demikian mewujudkan keruangan sebagai suatu bentuk, suatu ekspresi khusus yang berhubungan dengan dinamika waktu dari gerakan itu.

a. Ruang imejiner

Ruang imejiner yaitu memiliki kesan sentuhan dalam emosional. Kemudian gerak itu sendiri mengandung ruang, dan ruang itu juga ada disekeliling penari yang memungkinkan tubuh dapat bergerak menjangkau atau mewujudkan suatu keruangan.

\section{b.1 Positif dan Negatif}

Wujud dari bentuk ruang positif adalah keruangan yang ditempati secara nyata oleh obyek atau dalam hal ini desain wujud gerak tari. Sementara ruang negatif adalah keruangan yang kosong atau nihil diantara obyek-obyek atau wujud desain gerak. Didalam ruang gerak tari CangCang terdapat pemahaman wujud ruang positif dan ruang negatif ini secara sederhana dan cukup jelas ketika memahami ruang gerak seperti Contoh pada gerak lapah ngapai menunjukan bahwa yang dimaksud dengan wujud ruang positif adalah yang di tempati oleh tubuh penari sedangkan wujud ruang negatif adalah keruangan yang tidak di tempati oleh tubuh penari atau disekitar tubuh penari.

\section{b.2 Arah}

Pada tari Cang-Cang terdapat 4 arah hadap yang digunakan yaitu depan, belakang, samping, dan diagonal. Pada arah hadap ini dilakukan pada saat pergantian ragam gerak dari ragam gerak belibis yang semula menghadap diagonal menjadi berganti arah depan. Selain itu contoh lain yaitu pada ragam gerak jerambah 2 orang penari saling berhadapan 1 penari menghadap depan dan satu penari menghadap ke belakang. 
b.3 Pola Lantai

Pada tari Cang-Cang terdapat pola lantai membentuk huruf $\mathrm{V}$, vertikal, horizontal, zigzag, berhadapan, dan lingkaran. Pada pola lantai huruf $\mathrm{V}$ pada saat ragam gerak lapah ngapai, awal tarian para penari mengambil ancang-ancang untuk membentuk pola huruf V. Pola lantai vertikal pada saat gerak nguntai pungu ngehantak kukut para penari membentuk pola lantai vertikal lalu menuju pola lantai horizontal. Pola lantai zigzag pada saat gerak nyirup bunge para penari bergerak membentuk pola zigzag. Pola lantai berhadapan pada saat penari mengajak penonton ikut menari diatas pentas. Pola lantai lingkaran pada saat seluruh penari dan penonton berpegangan menjadi satu sebagai simbol kebersamaan.

b.4 Level

Level yang digunakan dalam tari Cang-Cang hanya menggunakan level sedang dan rendah. Gerakan yang menggunakan level sedang iyalah gerak sumping kanan, gerak nguntai pungu ngehantak kukut, gerak nyirup bunge, gerak ngawi ngajak. Sedangkan gerak yang menggunakan contoh level rendah iyalah gerak ngehasta pogat, gerak nyiruk badan, gerak bang kelibang.

b.5 Dimensi

Dimensi didalam tari merupakan jarak jangkauan. Seperti contoh yang ada di dalam gerak tari Cang-Cang lapah ngapai memiliki jangkaun gerak bidang vartikal karena memiliki jangkauan semula di sudut belakang sehingga mengarah jangkauan sudut depan.

C. Ruang Nyata

Ruang nyata merupakan area pentas sebagai tempat dimana penari melakukan aktifitas bergeraknya. Didalam tari Cang-Cang ruang nyata terdapat pada ruang pentas yang digunakan adalah ruang pentas terbuka selaiin itu terdapat pola lantai dan arah hadap yang menggunakan ruang area pentas.

\section{Elemen Estetis Waktu}

Waktu adalah sebagai elemen estetis, karena sebetulnya seorang penari atau koreografer sedang dalam proses penciptaan sebuah desain atau struktur waktu berlangsung maka berarti ada sebuah satuan waktu yang dibagibagi sesuai dengan tujuannya.

1. Ritme 
Ritme dapat diartikan dari serangkaian bunyi sama atau tidak sama panjangnya yang sambungmenyambung. Ritme dalam tari merupakan bagian dari waktu dalam setiap gerak tidak hanya cepat atau lambat tapi juga pengabungan antara keduannya yang dibentuk secara teratur sehingga terwujud gerakangerakan ritmis dan tidak membosankan.

Waktu digambarkan dengan penciptaan yang sudah didesain terstruktur; ketika gerakan berlangsung maka ada satuan waktu yang dibagibagi sesuai dengan tujuannya. Didalam gerakan tari Cang-Cang ritme gerak awal sampai dengan gerakan akhir tidak memiliki pengulangan gerak baik di awal gerakan sampai dengan gerakan akhir.

\section{Tempo}

Merupakan cepat atau lambatnya suatu tarian. Artinya ketika seorang penata tari mencipta satu motif gerak yang terdiri dari 8 hitungan atau ketukan maka penata tari tersebut akan menetukan bagian-bagian mana yang harus cepat dan bagian mana yang harus lambat. Kemudian tempo yang terdapat pada tari Cang-Cang mulanya gerak lapah ngapai menggunakan tempo lambat dan ketika berada di pertengahan tarian gerak belibis maka tempo yang digunakan cepat. pada gerakan mengajak tamu ikut menari dipanggung gerak nyung sung tamu tempo yang digunakan berubah menjadi tempo lambat kembali Hingga bagian terakhir tarian juga menggunakan tempo lambat.

3. Durasi

Durasi dapat dipahami sebagai jangka waktu yang terdapat pada sebuah tarian dari awal hingga akhir selama tarian tersebut berlangsung dan biasanya diukur dalam hitungan menit atau panjang pendeknya sebuah tarian tersebut di pentaskan. Batas waktu yang di gunakan pada tari Cang-Cang berkisaran 6-7 menit.

Gerak didalam tari Cang-Cang dimulai dari gerak lapah ngapai (gerak masuk), selanjutnya gerak ngawai ngajak, gerak sumping kanan, gerak nyiruk badan mutar kiri kanan, gerak ngutai pungu ngehantak kukut, gerak Bang Kelibang, gerak ngehasta pogat, gerak belibis, gerak nyilang kukut nope pungu, gerak ngotikkon jeriji, gerak nyirup bunge, gerak beguyong kiri kanan, gerak step patoh, gerak tunjuk 
langet, gerak nyungsung tamu, gerak bergilir nongah, gerak jerambah, gerak nyeruksuk dan gerak hormat akhir. Dalam tari Cang-Cang yang termasuk kedalam gerak Movemen yaitu gerak lapah ngapai, gerak ngehasta pogat, gerak belibis, gerak ngotikkon jeriji, dan gerak beguyong kiri kanan. Sedangkan yang termasuk kedalam gerak Motion yaitu gerak nyung sung tamu, gerak begilir nongah, gerak jerambah, dan gerak nyeruksuk.

Penunjang tari tersebut merupakan Ruang imajiner dan ruang nyata, ruang imajiner yaitu gerak itu sendiri mengandung ruang, dan ruang itu juga ada disekeliling penari yang memungkinkan tubuh dapat bergerak menjangkau atau mewujudkan keruangan. Selain itu ruang imajiner disebut dengan ruang positif dan negatif wujud dari bentuk ruang positif adalah keruangan yang ditempati secara nyata oleh obyek atau dalam hal ini desain wujud gerak tari. Sementara ruang negatif adalah keruangan yang kosong atau nihil diantara obyek-obyek atau wujud desain gerak. Didalam ruang gerak tari Cang-Cang terdapat pemahaman wujud ruang positif dan ruang negatif ini secara sederhana dan cukup jelas ketika memahami ruang gerak. Sedangkan ruang nyata merupakan area pentas sebagai tempat dimana penari melakukan aktifitas bergeraknya.

Dalam tari Cang-Cang hanya menggunakan lever rendah dan level sedang saja, dengan pola lantai yang membentuk $V$, pola lantai berbentuk vertikal, pola lantai berbentuk horizontal, pola lantai berbentuk zigzag, pola lantai berhadapan dan pola lantai berbentuk lingkaran. Selain itu didalam tari CangCang terdapat Ritme gerak, ritme gerak adalah elemen yang ada di dalam seni tari yang diawali dan juga diakhiri suatu gerakan atau beberapa rangkaian gerak. Didalam tari Cang-Cang gerak awal hingga gerak akhir tidak memiliki gerak penggulangan. Tempo yang terdapat juga sama yaitu pada gerakan awal hingga pertengahan tarian menggunakan tempo cepat sedangkan pada gerakan mengajak tamu ikut menari di panggung tempo yang digunakan tempo lambat hingga berakhirnya tarian juga menggunakan tempo lambat. Dengan durasi pertunjukan berkisar 6-7 menit. 


\section{SIMPULAN}

Tari Cang-Cang adalah tarian khusus dalam upacara adat perkawinan yang dipruntukan bagi keluarga kedua belah mempelai dan ditarikan oleh kedua mempelai dan kedua orang tua mempelai sebagai simbolis suatu kegembiraan, bahwa antara mereka terjadi suatu ikatan bebesanan merupakan suatu kehormatan juga sebagai mempelai sebagai suami istri. Tari Cang-Cang artinya mengangkat kain setinggi tungkai atas sampai tercang-Cang pada hakikatnya tari Cang-Cang merupakan tarian tradisional namun seiring berjalanya waktu terjadi penambahan gerak. Berbeda dengan jenis tari lainnya, tari Cang-Cang ditampilkan pada saat penghujung acara pesta perkawinan sebagai hiburan.

Tari Cang-Cang yang merupakan tarian kota Kayuagung yang sudah ada, diciptakan oleh Nyonya Eli Tokia pada tahun 1962, kemudian tari Cang-Cang sempat berhenti ditarikan kemudian ditarikan kembali pada tahun 1977, tetapi pada tahun 1978 oleh adik dari Nyonya Eli Tokia kembali mempublikasikan tari
Cang-Cang ini dengan diajarkannya para penari khususnya pada penari kayuagung, lalu fungsi tarian CangCang ini difungsikan untuk kegembiraan atau hiburan masyarakat yang sekaligus melibatkan penonton ikut menari.

Dengan memiliki ragam gerak Gerak didalam tari Cang-Cang dimulai dari gerak lapah ngapai (gerak masuk), selanjutnya gerak ngawai ngajak, gerak sumping kanan, gerak nyiruk badan mutar kiri kanan, gerak ngutai pungu ngehantak kukut, gerak bang kelibang, gerak ngehasta pogat, gerak belibis, gerak nyilang kukut nope pungu, gerak ngotikkon jeriji, gerak nyirup bunge, gerak beguyong kiri kanan, gerak step patoh, gerak tunjuk langet, gerak nyungsung tamu, gerak bergilir nongah, gerak jerambah, gerak nyeruksuk dan gerak hormat akhir. Dalam tari CangCang yang termasuk kedalam gerak Movemen yaitu gerak lapah ngapai, gerak ngehasta pogat, gerak belibis, gerak ngotikkon jeriji,dan gerak beguyong kiri kanan. Sedangkan yang termasuk kedalam gerak Motion yaitu gerak nyung sung tamu, gerak begilir nongah, gerak jerambah, dan gerak nyeruksuk dan gerak hormat akhir. Tempo yang terdapat juga sama yaitu 
pada gerakan awal hingga tempo lambat hingga berakhirnya tarian pertengahan tarian menggunakan juga menggunakan tempo lambat. tempo cepat sedangkan pada gerakan Dengan durasi pertunjukan berkisar 6-7 mengajak tamu ikut menari di menit. panggung tempo yang digunakan

\section{DAFTA \\ R PUSTAKA}

Bahari, N. (2014). Kritik Seni Wacana, Apresiasi dan Kreasi. Yogyakarta: Pustaka Belajar.

Budi, R. L. (2017). Pengetahuan Dasar Kesenian. Depok: PT Rajarafindo Persada.

Hadi, Y. (2007). Kajian Tari Teks dan Konteks. Yogyakarta: Pustaka Book Publisher. . (2016). Koreografi Bentuk-Teknik-Isi. Yogyakarta: Cipta Media. (2018). Revitalisasi Tari Tradisional. Yogyakarta: Cipta Medika.

Maryono. (2015). Analisis Tari. Surakarta: ISI Press.

Moleong, L. J. (2017). Metodologi Penelitian Kualitatif. Bandung: PT Remaja Rosdakarya.

Rahayu, F. (2015). Kajian EStetis Koreografis Tari Gembyong Retno Kusumo Di Sanggar Soerya Soemirat Kota Surakarta . Seni Tari, 1.

Rochayati, R. (2014). Sejarah dan Analisis Tari. Palembang: Penerbit Komunitas Titik Awal.

. (2017). Seni Tari Atara Ruang dan Waktu. Sitakara : Jurnal Pendidikan Seni Dan Seni. 2017. Edisi 3 No. 3. Prodi Sendratasik : FKIP Universitas PGRI Palembang.

(2019). Bentuk Gerak Tari Srimpi Kadang Premati Sebagai Materi Pembelajaran Pada Mata Kuliah Sejarah Dan Analisis Tari Di Universitas PGRI Palembang. (Online), https://jurnal.univpgri palembang.ac.id/index.php/sitakara/article/download/2345/2159.

Safirah, A. (2018). Kajian Dinamika Pertunjukan Tari Rumeksa Di Kota Purwokerto. SeniTari, 1.

Sugiono. (2011). Metode Penelitian Kuantitatif Kualitatif dan R\&D. Bandung: Alfabeta, CV. Supriantini. (2014). Sosiologi Tari. Palembang: Noer Fikri Offset. 
Widyastutieningrum, S R dan Dwi W. (2014). Pengantar Koreografi. Surakarta : ISI PresS Surakarta. 